\title{
The assessment of the suburbanisation degree of Warsaw Functional Area using changes of the land development structure
}

\begin{abstract}
The paper presents the analysis of spatial suburbanization using a multiindicator method. Based on features related to geodetic areas (according to the directions of their use) such as built-up areas, urbanised lands, arable lands, residential, recreation and leisure areas, road transport areas as well agricultural and forest areas transformed into local land development plans - six suburbanization indicators were developed. After the standardisation of such indicators, a summary index was obtained making it possible to determine the suburbanization degree. The validation of the proposed method was made by comparing individual municipalities with the unit type determined using the Webb method. The analysis made it clear that the only four units with spatial features of the city lying in the proximity of Warsaw, for which Polish capital could be enlarged are: Piastów, Pruszków, Marki, Józefów and possibly Sulejówek.
\end{abstract}

Keywords

Suburbanisation • land use structure $\cdot$ municipality $\bullet$ urban sprawl

(c) University of Warsaw - Faculty of Geography and Regional Studies
Konrad Podawca ${ }^{1}$, Krzysztof Karsznia², Agata Pawłat-Zawrzykraj ${ }^{3}$

Department of Civil Engineering,

Faculty of Civil and Environmental Engineering,

Warsaw University of Life Sciences - SGGW, Poland

${ }^{1}$ e-mail: konrad_podawca@sggw.pl

${ }^{2} e$-mail: krzysztof karsznia@sggw.pl

${ }^{3}$ e-mail: agata_pawlat_zawrzykraj@sggw.pl

Received: 11 January 2019

Accepted: 6 May 2019
Introduction

The increasing urban tendency, most often reflected in the absorption of arable land into city areas, is an inevitable but ongoing process. According to the French Alliance for Cities and Territorial Development (PFVT 2019), between now and 2030, cities will be inhabited by $80 \%$ of the earth's population, which is over 4 billion dwellers. The growth of cities is, therefore, inevitable; hence, the process of appropriate urban planning takes on significance. Around cities, there are temporary developing areas - specific zones between the city and agricultural land where the ongoing change in land use related to the proximity of cities is clearly visible (Sorensen 2016). The way in which the suburban areas are transformed is very diverse and difficult to generalise. In part, this is also a process dependent on the nature and size of the core city itself, but it is largely caused by physical features, natural barriers, transport accessibility and economic - including land production - value. The transformation of the suburban area may take on a chaotic form, called urban sprawl, but can also represent a precise orientation, e.g. in wedge-shaped form along transport corridors. It is not uncommon that within the city structure, areas that are not entirely urbanised are included; however, outside its administrative areas, one can find fully urbanised villages (Heffner 2011).

Nowadays, it is considered desirable to develop compact city structures with a higher intensity of their spatial use which can be called 'inward development' (Soltys 2010). In this context, the city should primarily absorb the areas with the greatest 'degree of urbanity'.

The historical development of Warsaw took place in stages. Its northern and southern quarters were incorporated in the early 18th century. This process has progressed over centuries. The most intensive enlargement of the city borders took place in 1951 when the largest of the current districts were joined to the city structure.

The development of Warsaw has always been formed by economic, demographic and spatial determinants. Never before has there been a proposal for a dynamic, one-off enlargement of Warsaw from $517 \mathrm{~km}^{2}$ to about $1,500 \mathrm{~km}^{2}$. Such a solution appeared in the draft legal act concerning the capital city of Warsaw, dated January 30, 2017 (Draft Act on the Constitution of the Capital City of Warsaw 2017). Increasing the Polish capital by 32 municipalities would triple its total area. In terms of area, and compared to other European cities (Demographia, 2018), Warsaw is currently located in 31 st place, whereas if it had been enlarged, it would have been in 4 th position right after Paris $\left(2,723 \mathrm{~km}^{2}\right)$, Essen/Düsseldorf $\left(2,642 \mathrm{~km}^{2}\right)$ and London $\left(1,623 \mathrm{~km}^{2}\right)$.

It should be obvious that the legislative process related to the delimitation of the area to grant a settlement city status or incorporate it into the city area is only the effect or the consequence of in-depth analyses during which the given area is considered in the urban-shaping context including:

- urbanisation, suburbanisation and so-called 'rurbanisation' processes;

- endogenous and exogenous functions;

- many natural, historical, demographic, social, economic and infrastructural factors.

The studies of urbanisation processes that take place around cities are needed both in a theoretical and practical 
sense, considering the specificity of processes occurring in a given suburban area. The analyses undertaken by the authors may apply in both cases.

\section{Features and properties of suburbanisation}

Urbanisation and suburbanisation have still been the ongoing processes shaping the contemporary look of the world. Due to the diverse nature of these phenomena, as well as the variability in time and space, we encounter many problems in the research and regular assessment of their intensity, choice of measures or administrative and investment decisions (Śleszyński 2009; Czarnecki 2010). In the relevant subject literature, the diversity of urbanisation of suburb areas is widely described considering demographic, economic, socio-cultural, natural landscape and spatial factors (Kutkowska et al. 2010; Małek 2011; Zegar et al. 2016; Mikołajczyk \& Raszka 2016; Harasimowicz 2018). The set of variables used in the study of the urbanisation level and dynamics is extensive, considering:

- the demographic aspect - these include a natural increase, the migration attractiveness ratio, the percentage of the population of working age, the fertility rate of women of reproductive age or number of marriages (Kutkowska et al 2010; Spórna 2018);

- the economic aspect - parameters including the number of private non-agricultural economic entities per 1,000 people of working age, the percentage of working women among women of working age (Kutkowska et al. 2010), the percentage of population whose livelihood comes from non-agricultural sources, the number of economic entities (Sokołowski 2015), demand per citizen, share of GDP in an administrative unit (Śleszyński 2012), GDP per citizen, gross value added in PLN per citizen, added value of market services per citizen, the number of companies per 1,000 citizens, unemployment rate, municipality budget incomes, investment expenses (Kutkowska et al. 2010);

- the social aspect - inter alia, the number of employees in industry and services, the average living area or the intensity of using cultural and leisure facilities (Małek 2011), the number of citizens utilising treatment plants, net schooling rate for children of preschool age, number of pharmacies per 1,000 citizens (Kutkowska et al. 2010), the ratio of workplaces to residential addresses (Sokołowski 2015), the number of flats per 1,000 citizens, usable floor area (Śleszyński 2012);

- the infrastructural and spatial aspect - inter alia, the character of functional domination, changes of arable land area in cadastral units (Jaroszewicz et al. 2018), the level of technical and infrastructural equipment, implementation of a spatial structure and built-up areas characteristic of a city structure, as well as an enacted spatial development plan (Sokołowski 2015), the increase in residential areas (Śleszyński 2012) but also the population density per $1 \mathrm{~km}^{2}$, the density of water pipelines per $1 \mathrm{~km}^{2}$, the ratio of new flats to overall residential resources, the number of sewage water connections per 1,000 flats (Kutkowska et al. 2010);

- the sociological aspect expressed by lifestyle changes changes in the forms of dwelling, living, nutrition, dress, organising working and free time, leisure, as well as changes in the family structure, social relations in local environments or mentality (Gutowski 2006).

Regarding the assumed analysis, the most interesting is the spatial aspect. In suburbanisation studies, the indicators mostly considered related to the number of local land development plans, as well as the changes they provide to land use (Mrozik \& Wiśniewska 2013, Podawca 2015, Podawca \& Mrozik 2019). The parameters related to the spatial structure in the suburbanisation context, such as the share of urbanised areas, the share of residential areas unrelated to agriculture, and the relation of residential areas to farm buildings constitute the basis for assessing the urbanisation processes (Degórska 2012; Zydroń \& Szczepański 2012; Mrozik, Bossy; Zaręba 2012). The authors also believe that the immanent feature of the urban area is the existence of public spaces (Gyurkovich 2007). In suburbanisation, there are particularly important recreational and leisure areas, which should co-exist with residential areas, increasing their attractiveness. Enlarging the village and changing its character due to the reduction of arable land and its allocation for housing, leisure, public or industrial purposes is also associated with the increase in building density, the improvement of transport infrastructure or the emergence of other service functions (Małek 2011).

In the subject literature, there are also variables used in the spatial aspect such as population density, the density of the water supply network, number of sewers per 1,000 dwellings or the percentage of newly completed flats in general housing resources (Kutkowska et al. 2010). The problem is so vibrant, that the above variables could also be applied in demographic, economic or social aspects, and are directly dependent on the spatial structure which is superior in this case. The discussed problem is currently the research subject for urban sprawl worldwide, concerning the European cities of Barcelona (Roca et al. 2004), Rome (Di Zio \& Montanari 2010), the capital of South Korea - Seoul (Woo 2014), Moscow (Brade \& Rudolph 2004) and metropolitan areas in the USA (Huang et al. 2017).

Regarding domestic conditions, the analysis of the Polish Academy of Sciences showed that the suburbanisation process is most advanced in the metropolitan area of Gdańsk-GdyniaSopot, Poznań, Lublin, Radom, Szczecin and, of course, the capital city of Warsaw (Lisowski and Grochowski 2008, Parysek 2008, Podawca \& Mrozik 2019). Despite the fairly obvious urbanisation process of rural, suburban areas, it takes on a much greater significance considering the sprawl of cities, increasing their areas and the process of urbanisation (Mitchell 2008; Bhatta 2010; Tivari \& Goel 2010; Karakayaci 2016).

\section{Research purpose and methodology}

It is commonly recognised that changes in suburban areas are caused by suburbanisation, defined as the sprawl proceeding from city centres outwards (Nijman \& Clery 2015). The authors assumed that the background for the decision on an administrative city enlargement should be, among other things, the assessment of the urbanisation level of the areas located within the range of socio-economic impact of a core city. The progressive processes of urbanisation mean that a clear division between the city and the village is blurred and the distinction between what is 'urban' and what is 'rural' becomes difficult. Thus, the authors set up the following research goal:

- to develop a set of spatial indicators representing characteristic features of urban areas;

- to develop a method for classifying areas in terms of the degree of their urbanisation.

At the same time, the authors formulated the thesis that Warsaw could be administratively enlarged while maintaining the features of the concentric system.

Due to the nature of the problem, a research procedure was sought that would consider a significant number of variables, with the simultaneous possibility of clarifying and grouping analysed objects. It was assumed that these conditions would be fulfilled by multi-indicator analysis, one of the fundamental multilevel methods playing a vital role in the spatial information system and is now a widely used tool (Borys 2005, Madsen et al. 2010, Hoła \& Nowobilski 2017). It was decided that the dominant 
aspect of urbanisation would be the spatial level that focuses on the methods of utilising areas included in the category 'Territorial division' in the 'National Geodetic Area' group (data from Geodesy and Cartography Head Office) collected in the Local Data Bank.

To assess the urbanisation level of the examined administrative units with corresponding variables, the following features were used:

- the total area of urbanised land $-\mathrm{P}_{\mathrm{gu}}[\mathrm{ha}$, related to:

- $\quad$ total municipality area $-P_{c g}$, showing the degree of urbanisation of the municipality $X_{1}$,

- $\quad$ total arable area $-P_{\mathrm{gr}}$ [ha], specifying the character of the municipality $\mathrm{X}_{2}$;

- the area of residential areas $P_{t m}$ [ha] which referred to:

- $\quad$ the car transportation area of $P_{t k}$ [ha], by showing the level of transportation accessibility of residential areas $X_{3}$,

- the recreation and leisure area $P_{t r w}$ [ha], by showing the extent of public and sport terrains $\mathrm{X}_{4}$ within inhabited areas;

- the total area of arable land for which plans for non-agricultural purposes have been changed $\mathrm{P}_{\mathrm{gr}}$ [ha], related to:

- $\quad$ total arable area $-\mathrm{P}_{\mathrm{gr}}$ [ha], determining the level of a municipality farmland status change $\mathrm{X}_{5}$;

- the total area of forest land for which the plan was designated

for non-forest purposes $\mathrm{P}_{\mathrm{glz}}$ [ha], which referred to:

- forest land area $-\mathrm{P}_{\mathrm{gl}}[\mathrm{ha}$ ], defining the degree of deforestation of the municipality land $X_{6}$.

Each municipality can be described by a vector of indicators $\mathrm{I}_{\mathrm{G}}$ :

$$
\mathrm{I}_{\mathrm{G}}=\left[\mathrm{X}_{1}, \ldots, \mathrm{I}_{\mathrm{n}}\right]
$$

where $G=1, \ldots, 39 ; X_{n}-$ an indicator adopted for analysis $(n=$ $1, \ldots, 6)$.

The set of municipalities of the Warsaw Functional Area $G_{\text {WOF }}$ is characterised by a two-dimensional matrix of indicators, given by the model:

$$
G_{W O F}=\left[\begin{array}{lll}
X_{1.1} & X_{n .1} & X_{6.1} \\
X_{1 . G} & X_{n . G} & X_{6 . G} \\
X_{1.39} & X_{n .39} & X_{6.39}
\end{array}\right]
$$

The values in the groups of particular indicators significantly deviate from each other. In this regard, as well as the fact that all indicators have the urbanisation stimulating character, the formula was applied to statistical normalisation:

$$
S_{n G}=\frac{X_{n G}}{\max X_{n G}}
$$

where: $X_{n g}$ - the value of an $n$-indicator in a G-municipality; max $\mathrm{X}_{\mathrm{nG}}$ - maximum value of the $n$-indicator, $\mathrm{S}_{\mathrm{nG}}-$ normalised value $\mathrm{x}_{\mathrm{nG}}$.

As a result of this process, a set of parameters $W_{\text {GWOF }}$ was created describing the analysed municipalities, saved in the form of a two-dimensional matrix. Each row contains values of all parameters for one municipality, and each column contains oneparameter data concerning all of them. This matrix is given as:

$$
W_{\text {GWOF }}=\left[\begin{array}{lll}
S_{1.1} & S_{n .1} & S_{6.1} \\
S_{1 . G} & S_{n . G} & S_{6 . G} \\
S_{1.39} & S_{n .39} & S_{6.39}
\end{array}\right]
$$

A synthetic form of the suburbanisation level of municipalities was obtained using data aggregation by applying the non-pattern method. As a result of processing the following formula:

$$
W_{s u b}=\frac{1}{x} \sum_{n=1}^{x} S_{n \cdot G}
$$

where: $W_{\text {sub }}$ - a synthetic indicator of spatial suburbanisation of municipalities; $\mathrm{n}-1,2, \quad \ldots, \mathrm{x}$; $x-$ the number of indicators included, the values from the range $0-1$ were obtained.

A higher value of the synthetic index means a higher degree of suburbanisation in the administrative unit.

The municipality is considered as the basic spatial unit covered by analyses. Such an approach was adopted because municipalities can conduct their local spatial policies, create inter-municipal relations, as well as being obliged to maintain interregional development tasks tied to their position in regional and sub-regional structures (districts, regions, functional areas, agglomerations, metropolises, etc.).

The territorial range was limited to the municipalities of the Warsaw Functional Area (WFA). The purpose of the selection of such a set was the systematically growing urban pressure on the areas near Warsaw and suggestions for incorporating these areas into the Polish capital. The relevant spatial analysis using numerical data was performed in ArcGIS software, version 10.4.1.

From the utilitarian point of view, the evaluation of selected municipalities of the WFA can provide the foundation to make a possible decision on including a given municipality in the capital city of Warsaw.

Municipality indicator characteristics of the Warsaw Functional Area

The sizes of indicators assessed (Table 1) affecting the level of urbanisation are the most diversified in the parameter $\mathrm{X}_{2}$ which defines the municipality character as more or less agricultural. In this regard, the current division into the type of administrative unit is visible because the highest values are assigned to urban municipalities. In this case, the rural municipalities of Jabłonna and Michałowice, as well as the urban-rural units of Wołomin, Łomianki and Piaseczno in which the ratio of residential and agricultural areas is above $30 \%$, deserve our attention. In other cases, the indicator strongly shows the agricultural character of municipalities. The situation is very similar in the context of the ratio of urbanised land to the municipality area. The exceptions are the municipalities of Izabelin and Zielonka, in which a significant share of forests is visible, limiting the urbanistic features of these areas.

In the case of the density of transportation related to residential areas, contrary to previous expectations, this indicator took on the highest value in non-urban units. The most significant values were observed in the urban-rural municipalities of Karczew, Ożarów Mazowiecki, Błonie, as well as in rural ones like Wiązowna, Wieliszew, Leszno and Czosnów. It proves that in these administrative units there is a transportation network, along which residential development can be implemented.

Considering the attractiveness of residential areas measured by the number of leisure and recreational areas, it was found that it does not depend on the unit type. Examples of a municipality with a small number of such areas are Józefów - an urban municipality, or Lesznowola - a rural village. The opposite, favourable situation can be observed in Żyrardów (urban), Jabłonna (rural) or Radzymin (urban and rural municipality). 
MISCELLANEA GEOGRAPHICA - REGIONAL STUDIES ON DEVELOPMENT

Vol. $23 \cdot$ No. $4 \cdot 2019 \cdot$ pp. 215-224 • ISSN: 2084-6118 • DOI: 10.2478/mgrsd-2019-0019

Table 1. Features and spatial suburbanisation indicators of the WFA municipalities (own elaboration)

\begin{tabular}{|c|c|c|c|c|c|c|c|c|c|c|c|c|c|c|c|}
\hline \multirow{2}{*}{ Municipality } & \multicolumn{9}{|c|}{ Values of the spatial structure features* [ha] } & \multicolumn{6}{|c|}{ Spatial urbanisation indicators [-] } \\
\hline & $\mathbf{P}_{\mathrm{cg}}$ & $\mathbf{P}_{\mathrm{gr}}$ & $\mathbf{P}_{\mathrm{gu}}$ & $\mathbf{P}_{\mathrm{tm}}$ & $\mathbf{P}_{\mathrm{tk}}$ & $\mathbf{P}_{\mathrm{trw}}$ & $\mathbf{P}_{\text {grf }}$ & $\mathbf{P}_{\mathrm{glz}}$ & $\mathbf{P}_{1}$ & $x_{1}$ & $x_{2}$ & $\mathbf{x}_{3}$ & $x_{4}$ & $X_{5}$ & $\mathbf{X}_{6}$ \\
\hline Milanówek & 1344 & 445 & 762 & 506 & 126 & 7 & 126 & 5 & 86 & 0.56696 & 1.71236 & 0.24901 & 0.01383 & 0.28315 & 0.05814 \\
\hline $\begin{array}{c}\text { Podkowa } \\
\text { Leśna }\end{array}$ & 1013 & 34 & 190 & 118 & 54 & 1 & 0 & 34 & 773 & 0.18756 & 5.58824 & 0.45763 & 0.00847 & 0.00000 & 0.04398 \\
\hline $\begin{array}{c}\text { Grodzisk } \\
\text { Mazowiecki }\end{array}$ & 10740 & 7322 & 2153 & 916 & 640 & 21 & 3210 & 0 & 775 & 0.20047 & 0.29405 & 0.69869 & 0.02293 & 0.43840 & 0.00000 \\
\hline Jaktorów & 5530 & 4135 & 792 & 362 & 201 & 2 & 857 & 36 & 429 & 0.14322 & 0.19154 & 0.55525 & 0.00552 & 0.20726 & 0.08392 \\
\hline Legionowo & 1354 & 80 & 1045 & 644 & 173 & 12 & 0 & 59 & 173 & 0.77179 & 13.0625 & 0.26863 & 0.01863 & 0.00000 & 0.34104 \\
\hline Jabłonna & 6480 & 2138 & 820 & 409 & 224 & 80 & 147 & 25 & 2833 & 0.12654 & 0.38354 & 0.54768 & 0.19560 & 0.06876 & 0.00882 \\
\hline Nieporęt & 9604 & 3356 & 921 & 408 & 267 & 31 & 421 & 59 & 4163 & 0.09590 & 0.27443 & 0.65441 & 0.07598 & 0.12545 & 0.01417 \\
\hline Wieliszew & 10609 & 5754 & 1006 & 249 & 369 & 10 & 0 & 31 & 2896 & 0.09483 & 0.17483 & 1.48193 & 0.04016 & 0.00000 & 0.01070 \\
\hline Halinów & 6309 & 4106 & 801 & 391 & 261 & 5 & 840 & 37 & 1062 & 0.12696 & 0.19508 & 0.66752 & 0.01279 & 0.20458 & 0.03484 \\
\hline Sulejówek & 1931 & 495 & 780 & 477 & 146 & 27 & 41 & 90 & 525 & 0.40394 & 1.57576 & 0.30608 & 0.05660 & 0.08283 & 0.17143 \\
\hline $\begin{array}{l}\text { Nowy Dwór } \\
\text { Mazowiecki }\end{array}$ & 2821 & 680 & 1280 & 178 & 144 & 8 & 0 & 0 & 207 & 0.45374 & 1.88235 & 0.80899 & 0.04494 & 0.00000 & 0.00000 \\
\hline Czosnów & 12845 & 7123 & 729 & 193 & 334 & 3 & 1475 & 11 & 3593 & 0.05675 & 0.10234 & 1.73057 & 0.01554 & 0.20708 & 0.00306 \\
\hline Józefów & 2391 & 316 & 1029 & 616 & 197 & 0 & 0 & 231 & 619 & 0.43036 & 3.25633 & 0.31981 & 0.00000 & 0.00000 & 0.37318 \\
\hline Otwock & 4731 & 1091 & 1393 & 679 & 339 & 17 & 353 & 357 & 1871 & 0.29444 & 1.27681 & 0.49926 & 0.02504 & 0.32356 & 0.19081 \\
\hline Karczew & 8150 & 4574 & 674 & 203 & 267 & 5 & 46 & 0 & 1907 & 0.08270 & 0.14735 & 1.31527 & 0.02463 & 0.01006 & 0.00000 \\
\hline Wiązowna & 10212 & 5816 & 845 & 267 & 348 & 11 & 172 & 1 & 3212 & 0.08275 & 0.14529 & 1.30337 & 0.04120 & 0.02957 & 0.00031 \\
\hline Góra Kalwaria & 14412 & 8643 & 1223 & 419 & 388 & 19 & 1845 & 183 & 2940 & 0.08486 & 0.14150 & 0.92601 & 0.04535 & 0.21347 & 0.06224 \\
\hline $\begin{array}{c}\text { Konstancin- } \\
\text { Jeziorna }\end{array}$ & 7858 & 4718 & 1080 & 511 & 294 & 20 & 852 & 267 & 977 & 0.13744 & 0.22891 & 0.57534 & 0.03914 & 0.18058 & 0.27329 \\
\hline Lesznowola & 6930 & 4884 & 1028 & 493 & 328 & 1 & 3345 & 194 & 912 & 0.14834 & 0.21048 & 0.66531 & 0.00203 & 0.68489 & 0.21272 \\
\hline Piaseczno & 12826 & 6267 & 2598 & 1365 & 593 & 19 & 1583 & 122 & 3626 & 0.20256 & 0.41455 & 0.43443 & 0.01392 & 0.25259 & 0.03365 \\
\hline Piastów & 576 & 71 & 505 & 286 & 95 & 5 & 34 & 0 & 0 & 0.87674 & 7.11268 & 0.33217 & 0.01748 & 0.47887 & 0.00000 \\
\hline Pruszków & 1919 & 549 & 1295 & 514 & 321 & 60 & 164 & 1 & 14 & 0.67483 & 2.35883 & 0.62451 & 0.11673 & 0.29872 & 0.07143 \\
\hline Brwinów & 6926 & 4779 & 1409 & 691 & 369 & 14 & 625 & 27 & 510 & 0.20344 & 0.29483 & 0.53401 & 0.02026 & 0.13078 & 0.05294 \\
\hline Michałowice & 3473 & 2049 & 976 & 524 & 273 & 12 & 898 & 0 & 269 & 0.28103 & 0.47633 & 0.52099 & 0.02290 & 0.43826 & 0.00000 \\
\hline Nadarzyn & 7345 & 4757 & 1046 & 474 & 341 & 8 & 317 & 54 & 1335 & 0.14241 & 0.21989 & 0.71941 & 0.01688 & 0.06664 & 0.04045 \\
\hline Raszyn & 4391 & 2808 & 815 & 450 & 244 & 9 & 0 & 0 & 653 & 0.18561 & 0.29024 & 0.54222 & 0.02000 & 0.00000 & 0.00000 \\
\hline Błonie & 8558 & 7570 & 843 & 197 & 257 & 22 & 715 & 0 & 16 & 0.09850 & 0.11136 & 1.30457 & 0.11168 & 0.09445 & 0.00000 \\
\hline Izabelin & 6501 & 578 & 523 & 311 & 160 & 3 & 95 & 55 & 5036 & 0.08045 & 0.90484 & 0.51447 & 0.00965 & 0.16436 & 0.01092 \\
\hline Leszno & 12508 & 6424 & 438 & 150 & 239 & 12 & 352 & 15 & 5214 & 0.03502 & 0.06818 & 1.59333 & 0.08000 & 0.05479 & 0.00288 \\
\hline Łomianki & 3883 & 1721 & 937 & 546 & 213 & 3 & 184 & 12 & 595 & 0.24131 & 0.54445 & 0.39011 & 0.00549 & 0.10691 & 0.02017 \\
\hline $\begin{array}{c}\text { Ożarów } \\
\text { Mazowiecki }\end{array}$ & 7127 & 6124 & 851 & 202 & 290 & 6 & 2896 & 0 & 55 & 0.11941 & 0.13896 & 1.43564 & 0.02970 & 0.47289 & 0.00000 \\
\hline Stare Babice & 6342 & 4443 & 559 & 267 & 216 & 2 & 1755 & 5 & 1227 & 0.08814 & 0.12582 & 0.80899 & 0.00749 & 0.39500 & 0.00407 \\
\hline Kobyłka & 1964 & 574 & 821 & 464 & 139 & 5 & 133 & 35 & 394 & 0.41802 & 1.43031 & 0.29957 & 0.01078 & 0.23171 & 0.08883 \\
\hline Marki & 2615 & 315 & 1212 & 569 & 224 & 4 & 315 & 115 & 915 & 0.46348 & 3.84762 & 0.39367 & 0.00703 & 1.00000 & 0.12568 \\
\hline Ząbki & 1098 & 203 & 556 & 319 & 102 & 5 & 0 & 0 & 325 & 0.50638 & 2.73892 & 0.31975 & 0.01567 & 0.00000 & 0.00000 \\
\hline Zielonka & 7948 & 257 & 659 & 269 & 113 & 13 & 0 & 129 & 6166 & 0.08291 & 2.56420 & 0.42007 & 0.04833 & 0.00000 & 0.02092 \\
\hline Radzymin & 12946 & 7321 & 1991 & 618 & 474 & 161 & 950 & 26 & 2885 & 0.15379 & 0.27196 & 0.76699 & 0.26052 & 0.12976 & 0.00901 \\
\hline Wołomin & 6166 & 3530 & 1439 & 746 & 320 & 2 & 0 & 38 & 940 & 0.23338 & 0.40765 & 0.42895 & 0.00268 & 0.00000 & 0.04043 \\
\hline Żyrardów & 1435 & 362 & 939 & 379 & 196 & 50 & 96 & 0 & 71 & 0.65436 & 2.59392 & 0.51715 & 0.13193 & 0.26519 & 0.00000 \\
\hline
\end{tabular}

Legend

\begin{tabular}{|c|c}
\hline & Minimum values \\
\hline & Maximum values
\end{tabular}

* data provided by the Local Data Bank for the year 2014; in the case of the parameters $P_{g r f}$ and $P_{g \mid z}$, maximum value concerns the period 2013-2016 
The progress of suburbanisation is immanently tied to the change in function of a terrain. In such cases, the most common process is the change of farmland status (from agricultural to residential) or its deforestation. Regarding the size of agricultural and forest areas allocated in local land development plans, the municipalities of Piastów and Marki are leading the way to assigning another function. This is the inevitable result of a small amount of arable land. The most significant planning level of the suburbanisation of rural areas occurs in Lesznowola, Ożarów Mazowiecki and Grodzisk Mazowiecki, while the smallest excluding cities - is in Wołomin, Raszyn and Wieliszew (Table 1).

While analysing the normalised indicators presented in Table 2, it is possible to observe how individual municipalities compare with the maximum value of a given indicator. Indeed, the municipality data groups are analogous with the division involving $X_{n}$ indicators. The municipalities with the most agricultural structure of land use (parameters $\mathrm{S}_{1}, \mathrm{~S}_{2}$ ) in which the values do not exceed $10 \%$ of the overall maximum are Leszno, Czosnów, Izabelin, Karczew and Wiązowna. One can also see how the comparison of geodetic built-up and agricultural areas with a large share of forests, can give a rural character to the urban unit - as is the case of Zielonka. Of course, the maximum values prevail in urban municipalities with Legionowo and Piastów as the most dominant ones.

What is more, the density of the transportation network related to residential areas is not the highest in urban municipalities. Comparing maximal values of the whole set, the lower ratio can be observed in Milanówek, Legionowo, Kobyłka, Sulejówek, Ząbki, Józefów and Piastów (below 20\%); however, the most advantageous are Ożarów Mazowiecki, Wieliszew, Leszno and Czosnów (over $80 \%$ ). Such a situation in rural units is affected by the small surface of residential terrain. Nevertheless, this value has a significant impact on the prospects of creating new urban areas.

One of the most interesting aspects we can consider is the level of the change in use of farmlands by giving them other purposes, which - compared to the municipality of Marki - is higher than $40 \%$ in the municipalities of Michałowice, Grodzisk Mazowiecki, Ożarów Mazowiecki, Lesznowola and Piastów. The most surprising observation is the lack of transformation of arable land for other purposes during the spatial planning process in municipalities: Wołomin, Raszyn and Wieliszew. The analysed factor does not indicate a complete lack of such a process. It is difficult, however, to judge ift due to the lack of data on the potential to change the status of farmlands at the request of individual farmers.

\section{Research results}

Regarding the assessment of the WFA municipalities based on six suburbanisation indices and - at the same time - diversification in the context of their possible inclusion in the capital city of Warsaw, a division into typological groups was used (Komornicki \& Śleszyński 2009, Kutkowska et al. 2010) following the principle:

- group I (high degree of spatial suburbanisation) municipalities: Legionowo, Marki, Piastów, Pruszków, Żyrardów and Józefów, in which the value of the synthetic indicator exceeds the mean and standard deviation $\mathrm{W}_{\text {sub }} \geq$ $\mathrm{W}_{\text {sub(mean.) }}+\mathrm{s}_{\text {Wsub }}$, i.e. greater than 0.31199 ;

- group II (average degree of spatial suburbanisation) municipalities: Lesznowola, Radzymin, Otwock, KonstancinJeziorna, Ożarów Mazowiecki, Sulejówek, Milanówek, Błonie, Czosnów and Leszno, in which $W_{\text {sub(mean.) }}+s_{\text {Wsub }}>$ $W_{\text {sub }} \geq W_{\text {sub(mean) }}$, i.e. within the range of $<0.22232 ; 0.31199$ ); group III (low degree of spatial suburbanisation) municipalities: Jabłonna, Nowy Dwór Mazowiecki, Kobyłka,
Góra Kalwaria, Michałowice, Grodzisk Mazowiecki, Wieliszew, Podkowa Leśna, Wiązowna, Ząbki, Stare Babice, Karczew, Nieporęt, Jaktorów, Brwinów, Piaseczno, Halinów and Nadarzyn, where the synthetic indicator fulfils the condition $\mathrm{W}_{\text {sub(mean.) }}>\mathrm{W}_{\text {sub }} \geq \mathrm{W}_{\text {sub(mean.) }}-\mathrm{s}_{\mathrm{Wsub}}$, i.e. $<0.13265$; 0.22232 );

- group IV (very low degree of spatial suburbanisation) municipalities: Zielonka, Łomianki, Izabelin, Wołomin and Raszyn, in which the synthetic indocator is smaller than $0.13265-$ i.e. $W_{\text {sub }}<W_{\text {sub(mean.) }}-S_{\text {Wsub }}$.

Considering the spatial distribution of particular municipalities, it should be noted that in the first ring from Warsaw, only the municipalities of Piastów, Pruszków, Marki and Józefów are characterised by significant urban features (i.e. urban, from the perspective of the land use structure). For rural and urbanrural units, among those located directly near the borders of Warsaw, there are Ożarów Mazowiecki, Konstancin-Jeziorna and Lesznowola. From the remaining municipalities with a high total spatial degree of suburbanisation, there are two rural ones: Leszno and Czosnów, two urban-rural: Błonie and Radzymin as well as two cities: Milanówek and Otwock. They are situated in the second centralisation ring within the Warsaw Functional Area. One can also observe four administrative units - Raszyn, Łomianki, Zielonka and Izabelin - neighbouring directly with Warsaw that present a low degree of spatial suburbanisation. In this case, particular attention should be paid to urban-rural municipalities (Łomianki and Raszyn), which despite the apparent urban character, considered as a whole, fall below expectations. In this regard, one may attempt to state that the suburbanisation is not unequivocally related to the distance and transport connections with Warsaw. The incorporation of municipalities with a high degree of urbanisation located in the proximity of Warsaw is in line with one of the development principles, i.e. the law of minimising effort (the maximum use of existing available resources and then the less accessible resources) (Chmielewski 2001).

In the case of the municipalities (mainly urban) with a high degree of spatial suburbanisation and located a greater distance from Warsaw, including them into the area of Warsaw, apart from the problem of urban sprawl, is associated with the need to overcome the so-called development thresholds of the city (mainly infrastructural and economical). Overcoming such problems requires significant financial resources although, in the long term, it may create individual development potential. At the same time, one can consider a very probable scenario in which some of the analysed units, more distant but well connected with Warsaw, have a chance for further multifunctional development as 'satellite centres' (sub-centres) of the Polish capital, preserving their administrative autonomy.

In order to verify the proposed method of suburbanisation assessment, the results were compared with the most frequently used demographic plane of the suburbanisation process (Zegar et al. 2016, Śleszyński 2012). It turned out that the indicators - mainly population growth - used during the assessment of social suburbanisation levels provide quite similar but not identical results as the indicators used to evaluate the land suburbanisation. Considering the suburban division of municipalities according to the Webb method, it can be concluded that major municipalities of WFA are characterised by a positive real increase (types A-D). In most cases, the relationship between demographic and spatial parameters can be observed among municipalities belonging to groups I and II (Table 3). In several units, despite the population increase, the degree of spatial suburbanisation is diversified (Figure 1). The most significant contrast between the demographic and spatial sphere is visible: 
MISCELLANEA GEOGRAPHICA - REGIONAL STUDIES ON DEVELOPMENT

Vol. $23 \cdot$ No. $4 \cdot 2019 \cdot$ pp. 215-224 • ISSN: 2084-6118 • DOI: 10.2478/mgrsd-2019-0019

Table 2. Values of normalised indices of suburbanisation in WFA municipalities (own elaboration)

\begin{tabular}{|c|c|c|c|c|c|c|c|c|c|}
\hline \multirow{2}{*}{ No. } & \multirow{2}{*}{ Municipality } & \multirow{2}{*}{ Municipality type * } & \multicolumn{7}{|c|}{ Values of normalised suburbanisation indicators [-] } \\
\hline & & & $\mathbf{S}_{1}$ & $\mathbf{S}_{2}$ & $\mathbf{S}_{3}$ & $\mathbf{S}_{4}$ & $\mathbf{S}_{5}$ & $\mathbf{S}_{6}$ & $\mathbf{W}_{\text {sub }}$ \\
\hline & Milanówek & urban & 0.64668 & 0.13109 & 0.14389 & 0.05310 & 0.28315 & 0.15579 & 0.23562 \\
\hline & Podkowa Leśna & urban & 0.21393 & 0.42781 & 0.26444 & 0.03253 & 0.00000 & 0.11786 & 0.17610 \\
\hline & Grodzisk Mazowiecki & urban-rural & 0.22865 & 0.02251 & 0.40373 & 0.08800 & 0.43840 & 0.00000 & 0.19688 \\
\hline & Jaktorów & rural & 0.16335 & 0.01466 & 0.32085 & 0.02121 & 0.20726 & 0.22487 & 0.15870 \\
\hline & Legionowo & urban & 0.88030 & 1.00000 & 0.15523 & 0.07152 & 0.00000 & 0.91388 & 0.50349 \\
\hline & Jabłonna & rural & 0.14433 & 0.02936 & 0.31647 & 0.75081 & 0.06876 & 0.02365 & 0.22223 \\
\hline & Nieporęt & rural & 0.10938 & 0.02101 & 0.37815 & 0.29165 & 0.12545 & 0.03798 & 0.16060 \\
\hline & Wieliszew & rural & 0.10816 & 0.01338 & 0.85632 & 0.15416 & 0.00000 & 0.02868 & 0.19345 \\
\hline & Halinów & urban-rural & 0.14481 & 0.01493 & 0.38572 & 0.04909 & 0.20458 & 0.09336 & 0.14875 \\
\hline & Sulejówek & urban & 0.46073 & 0.12063 & 0.17687 & 0.21727 & 0.08283 & 0.45937 & 0.25295 \\
\hline & Nowy Dwór Mazowiecki & urban & 0.51753 & 0.14410 & 0.46747 & 0.17252 & 0.00000 & 0.00000 & 0.21694 \\
\hline & Czosnów & rural & 0.06473 & 0.00783 & 1.00000 & 0.05967 & 0.20708 & 0.00820 & 0.22459 \\
\hline & Józefów & urban & 0.49087 & 0.24929 & 0.18480 & 0.00000 & 0.00000 & 1.00000 & 0.32083 \\
\hline & Otwock & urban & 0.33584 & 0.09775 & 0.28850 & 0.09610 & 0.32356 & 0.51130 & 0.27551 \\
\hline & Karczew & urban-rural & 0.09433 & 0.01128 & 0.76002 & 0.09454 & 0.01006 & 0.00000 & 0.16171 \\
\hline & Wiązowna & rural & 0.09438 & 0.01112 & 0.75315 & 0.15814 & 0.02957 & 0.00083 & 0.17453 \\
\hline & Góra Kalwaria & urban-rural & 0.09679 & 0.01083 & 0.53509 & 0.17406 & 0.21347 & 0.16680 & 0.19951 \\
\hline & Konstancin-Jeziorna & urban-rural & 0.15676 & 0.01752 & 0.33246 & 0.15024 & 0.18058 & 0.73232 & 0.26165 \\
\hline & Lesznowola & rural & 0.16920 & 0.01611 & 0.38445 & 0.00779 & 0.68489 & 0.57002 & 0.30541 \\
\hline & Piaseczno & urban-rural & 0.23104 & 0.03174 & 0.25103 & 0.05343 & 0.25259 & 0.09016 & 0.15166 \\
\hline & Piastów & urban & 1.00000 & 0.54451 & 0.19194 & 0.06711 & 0.47887 & 0.00000 & 0.38041 \\
\hline & Pruszków & urban & 0.76971 & 0.18058 & 0.36087 & 0.44807 & 0.29872 & 0.19141 & 0.37489 \\
\hline & Brwinów & urban-rural & 0.23204 & 0.02257 & 0.30857 & 0.07777 & 0.13078 & 0.14186 & 0.15227 \\
\hline & Michałowice & rural & 0.32054 & 0.03647 & 0.30105 & 0.08790 & 0.43826 & 0.00000 & 0.19737 \\
\hline & Nadarzyn & rural & 0.16243 & 0.01683 & 0.41571 & 0.06478 & 0.06664 & 0.10839 & 0.13913 \\
\hline & Raszyn & rural & 0.21170 & 0.02222 & 0.31332 & 0.07677 & 0.00000 & 0.00000 & 0.10400 \\
\hline & Błonie & urban-rural & 0.11235 & 0.00853 & 0.75384 & 0.42867 & 0.09445 & 0.00000 & 0.23297 \\
\hline & Izabelin & rural & 0.09176 & 0.06927 & 0.29728 & 0.03703 & 0.16436 & 0.02927 & 0.11483 \\
\hline & Leszno & rural & 0.03994 & 0.00522 & 0.92070 & 0.30708 & 0.05479 & 0.00771 & 0.22257 \\
\hline & Łomianki & urban-rural & 0.27523 & 0.04168 & 0.22542 & 0.02109 & 0.10691 & 0.05404 & 0.12073 \\
\hline & Ożarów Mazowiecki & urban-rural & 0.13619 & 0.01064 & 0.82958 & 0.11402 & 0.47289 & 0.00000 & 0.26055 \\
\hline & Stare Babice & rural & 0.10053 & 0.00963 & 0.46747 & 0.02875 & 0.39500 & 0.01092 & 0.16872 \\
\hline & Kobyłka & urban & 0.47680 & 0.10950 & 0.17310 & 0.04136 & 0.23171 & 0.23804 & 0.21175 \\
\hline & Marki & urban & 0.52864 & 0.29455 & 0.22748 & 0.02698 & 1.00000 & 0.33679 & 0.40241 \\
\hline & Ząbki & urban & 0.57757 & 0.20968 & 0.18477 & 0.06016 & 0.00000 & 0.00000 & 0.17203 \\
\hline & Zielonka & urban & 0.09457 & 0.19630 & 0.24274 & 0.18550 & 0.00000 & 0.05606 & 0.12920 \\
\hline & Radzymin & urban-rural & 0.17542 & 0.02082 & 0.44320 & 1.00000 & 0.12976 & 0.02415 & 0.29889 \\
\hline & Wołomin & urban-rural & 0.26619 & 0.03121 & 0.24787 & 0.01029 & 0.00000 & 0.10833 & 0.11065 \\
\hline & Żyrardów & urban & 0.74635 & 0.19858 & 0.29883 & 0.50640 & 0.26519 & 0.00000 & 0.33589 \\
\hline
\end{tabular}

Legend

\begin{tabular}{|c|c}
\hline & Minimum values \\
Maximum values
\end{tabular}

* The municipality is the basic unit of administrative division and local government in Poland.

It encompasses either a city (urban municipality) or only a rural area (rural municipality) as well as

a city with the surrounding rural area (urban-rural municipality). Such division is in accordance with the regulation of the Polish

Council of Ministers resulting from the legal act of 8 March 1990 regarding local government (plain text - Dz.U. 2018 pos. 994). 


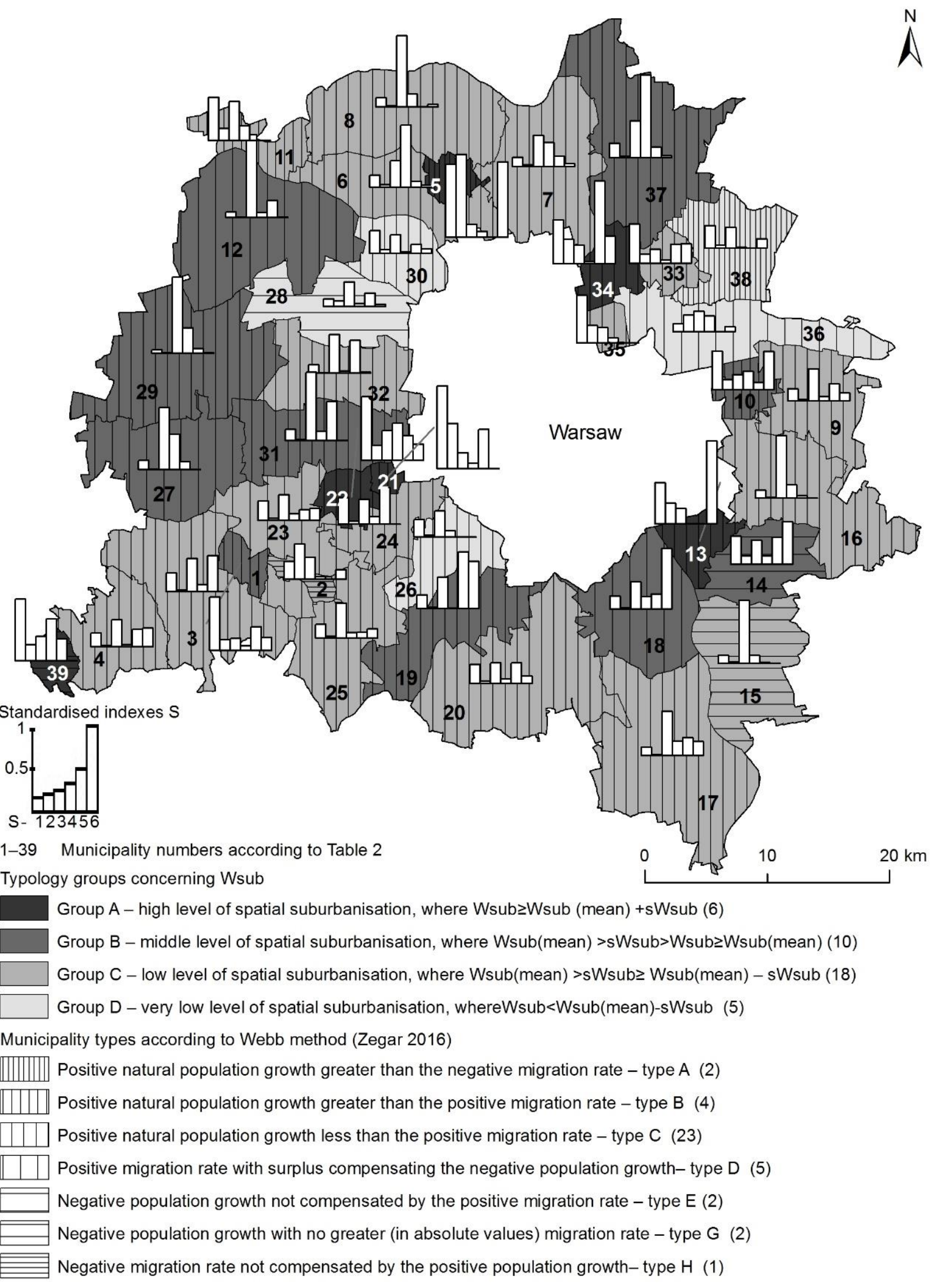

Figure 1. Spatial diversification of WFA municipalities according to suburbanisation level (own elaboration performed in ArcGIS) Source: Local Data Bank 
MISCELLANEA GEOGRAPHICA - REGIONAL STUDIES ON DEVELOPMENT

Vol. 23 • No. 4 • 2019 • pp. 215-224 • ISSN: 2084-6118 • DOI: 10.2478/mgrsd-2019-0019

Table 3. Distribution of WFA-municipality groups related to the Webb-type units (own elaboration)

\begin{tabular}{|c|c|c|c|c|c|c|c|c|c|c|c|c|c|c|c|c|c|}
\hline & \multicolumn{16}{|c|}{ Distribution of territorial units according to types based on the Webb method } \\
\hline & & \multicolumn{2}{|c|}{ A } & \multicolumn{2}{|c|}{ B } & \multicolumn{2}{|c|}{ C } & \multicolumn{2}{|c|}{ D } & \multicolumn{2}{|c|}{$\mathrm{E}$} & \multicolumn{2}{|c|}{$\mathbf{F}$} & \multicolumn{2}{|c|}{ G } & \multicolumn{2}{|c|}{ H } \\
\hline & & pcs & $\%$ & pcs & $\%$ & pcs & $\%$ & pcs & $\%$ & pcs & $\%$ & pcs & $\%$ & pcs & $\%$ & pcs & $\%$ \\
\hline \multirow{4}{*}{$\begin{array}{c}\text { Municipality } \\
\text { groups according } \\
\text { to summarised } \\
\text { suburbanisation } \\
\text { indicator }\end{array}$} & 1 & 1 & 2.56 & 1 & 2.56 & 0 & 0 & 3 & 7.69 & 0 & 0 & 0 & 0 & 1 & 2.56 & 0 & 0 \\
\hline & II & 0 & 0 & 2 & 5.13 & 3 & 7.69 & 4 & 10.3 & 1 & 2.56 & 0 & 0 & 0 & 0 & 0 & 0 \\
\hline & III & 0 & 0 & 1 & 2.56 & 1 & 2.56 & 14 & 35.9 & 0 & 0 & 0 & 0 & 1 & 2.56 & 1 & 2.56 \\
\hline & IV & 1 & 2.56 & 0 & 0 & 1 & 2.56 & 2 & 5.13 & 1 & 2.56 & 0 & 0 & 0 & 0 & 0 & 0 \\
\hline
\end{tabular}

Source: Local Data Bank

- $\quad$ in the municipality of Żyrardów, in which we observe both negative population growth and migration balance with simultaneous high rates of spatial suburbanisation;

- in the municipality of Wołomin, in which, despite the increase in population growth, we observe a slight degree of spatial suburbanisation.

The above examples of municipalities and the presented summary (Table 3 ) prove that the suburbanisation process should be considered simultaneously at all levels and not unilaterally (mainly in a demographic context).

\section{Conclusion}

Changes in geodetic areas according to the methods of their land use should be regarded as one of the criteria for assessing the urbanisation or suburbanisation processes. This is justified by the results obtained, which are not always relevant to the demographic approach. The possible enlargement of the administrative boundaries of Warsaw in the present land use situation by assessing the changes in geodetic areas, according to how they are used, can be considered only in the case of few municipalities (Piastów, Pruszków, Marki, Józefów or possibly Sulejówek). These municipalities met the examined urban criteria in terms of spatial structure. Hence, it should be emphasised that the formulated assumption was not confirmed. If the administrative boundaries of Warsaw were enlarged, therefore - according to urban theories considering the models of spatial structures of cities - we should apply a multi- or polycentric system developed by Harris and Ullman (Liszewski 2012).

On the other hand, the authors achieved the assumed goals. The proposed methodology for the assessment of spatial units in terms of the degree of urbanisation can also be applied to a different set of municipalities located near a large city. The limitation in applying the method is the maximum value for particular indicators used in the standardisation. This is not a universal value, but it results from the specificity of a given region, country or city. The research aimed to valorise individual spatial units within the area around a given city but not to compare individual agglomerations between them. Regarding the Warsaw Functional Area, the results obtained may be a contribution to further work and analyses on changes in the administrative boundaries of Warsaw.

\section{References}

Bhatta, B 2010, 'Analysis of Urban Growth and Sprawl from Remote Sensing Data', Advances in Geographic Information Science, vol. 17, Springer-Verlag Berlin Heidelberg, DOI 10.1007/978-3-642-05299-6_2.

Brade, I \& Rudolph, R 2004, 'Moscow, the global city? The position of the Russian capital within the European system of metropolitan areas', Area, vol. 36(1), pp. 69-80.

Czarnecki, A 2010, ,Procesy urbanizacji na obszarach wiejskich w Polsce' in Przestrzenne, społeczno-ekonomiczne zróżnicowanie obszarów wiejskich w Polsce. Problemy $i$ perspektywy rozwoju ['Urbanisation processes in rural areas in Poland' in Spatial socio-economic differentiation of rural areas in Poland. Problems and development perspectives'], eds. M Stanny \& M Drygas, Instytut Rozwoju Wsi i Rolnictwa PAN, Warszawa, pp. 61-80.

Chmielewski, JM 2001, Teoria urbanistyki w projektowaniu $i$ planowaniu miast ['Urban theory in designing and planning of cities']. Oficyna Wydawnicza Politechniki Warszawskiej.

Degórska, B 2012, ,Problemy planowania struktur przyrodniczych Obszaru Metropolitalnego Warszawy związane z żywiołową urbanizacją przestrzeni. Mazowsze' ['Problems of natural structure planning within Warsaw Metropolitan Area regarding vital urbanisation of space. Masovia'], Studia Regionalne, no. 10, pp. 89-106.
Demographia, 2018, Demographia World Urban Areas (Built Up Areas or World Agglomerations), 14th Annual Edition 201804. Available from: <http://www.demographia.com/dbworldua.pdf>. [26 March 2019].

Di Zio, S, Montanari, A \& Staniscia, B 2010, 'Simulation of urban development in the City of Rome', The Journal of transport and land use, vol. 3, no. 2, pp. 85-105.

French Alliance for Cities and Territorial Development, 2019, Partenariat français pour la ville et les territoires - PFVT. Available from: <https://www.diplomatie.gouv.fr/en/photospublications-and-graphics/publications/article/frenchalliance-for-cities-and>. [26 March 2019].

Gutowski, P 2006, Przestrzeń marzycieli. Miasto jako projekt utopijny ['The dreamers' space. The city as a utopian project'], Instytut Historii Sztuki UKSW, Warsaw, pp. 1-293.

Gyurkovich, J 2007, 'Miejskość miasta' ['The urban character of a city'], Czasopismo Techniczne, vol. 2-A/2007 pp. 105-118.

Harasimowicz, A 2018, 'Suburbanizacja a rola obszarów otaczających miasto-ujęcie teoretyczne' ['The suburbanisation versus the role of the areas surrounding a city - the theoretic approach], Studia Miejskie, vol. 29, pp. 115-130.

Heffner, K 2011, ,Semiurbanizacja a subrbanizacja. Ewolucja procesów w aglomeracji opolskiej', Studia Miejskie, vol. 3, pp. 17-34. 
Hoła, B \& Nowobilski, T 2018, 'Klasyfikacja polskich województw pod kątem wybranych wskaźników charakteryzujących budownictwo' ['Classification of Polish districts considering selected indicators characterising civil engineering'], Scientific Review Engineering and Environmental Sciences, vol. 27(3), pp. 310-318.

Huang, X, Yang, J, Güneralp, B \& Burris, M, 2017, 'U.S. metropolitan spatial structure evolution: investigating spatial patterns of employment growth from 2000 to 2010', Urban Science, vol. 1, no. 28. DOI:10.3390/urbansci1030028.

Jaroszewicz, J, Budzyński, T, Krupowicz, W, Majewska, A \& Sajnóg, N 2018, 'A method for identification of future suburbanisation areas', Geodetski Vestnik, vol. 62(3), pp. 472-486.

Jun, MJ \& Kim, HJ 2017, 'Measuring the effect of greenbelt proximity on apartment rents in Seoul', Cities, vol. 62, pp. $10-22$.

Karakayaci, Z 2016, 'The concept of urban sprawl and its causes', The Journal of International Social Research, vol. 9, issue 45, pp. 815-818.

Komornicki, T \& Śleszyński, P 2009, 'Typologia obszarów wiejskich pod względem powiązań funkcjonalnych i relacji miasto-wieś, Analiza zróżnicowania i perspektyw rozwoju obszarów wiejskich w Polsce do 2015 roku' ['Typology of the rural areas regarding functional connections and the cityvillage relation, The analyse of differences and development perspectives of rural areas in Poland until 2015'] in Studia Obszarów Wiejskich, ed. J Bański, vol. 16, Warsaw, pp. 9-37.

Kutkowska, B, Czarnecki, A, Łabędzki, H, Struś, M, Jabłoński, W, Iwaszko-Niziałkowska, K \& Głaz, M 2010, Modele rozwoju dla terenów urbanizujących się w obrębie wielofunkcyjnych obszarów wiejskich ['The development models for urbanising areas within multi-functional rural areas'], Bimart, Wrocław.

Lisowski, A \& Grochowski, M 2008, ,Procesy suburbanizacji. Uwarunkowania, formy i konsekwencje' in Ekspertyzy do Koncepcji Zagospodarowania Przestrzennego Kraju ['Suburbanisation processes. Conditions, forms and consequences. Expertise for the Concept of Spatial Development of Poland'], eds. K Saganowski, M Zagrzejewska-Fiedorowicz \& $\mathrm{P}$ Żuber $\mathrm{P}$, Ministerstwo Rozwoju Regionalnego, Warszawa, vol. 1, pp. 217-280.

Liszewski, S 2012, Geografia urbanistyczna ['The urban geography'], Wydawnictwo Naukowe PWN, Warsaw.

Madsen, MF, Kristensen, SBP, Fertner, C, Busck, AG \& Jørgensen, G 2010, 'Urbanisation of rural areas: A case study from Jutland, Denmark', Geografisk Tidsskrift/Danish Journal of Geography, vol. 110, no. 1, pp. 4763.

Małek, J 2011, ,Historyczne i współczesne uwarunkowania procesów suburbanizacji', Przestrzeń i Forma, no 16, pp. 431-442.

Mikołajczyk, M \& Raszka, B 2016, 'Indicators of the environmental aspect of spatial order as a tool for environmental protection in suburban areas', Geomatics, Land Management and Landscape, no. 3, pp. 105-114.

Mitchell, CJA 2008, 'Counterurbanization and the Growth of Canada's Rural and Small Town Municipalities: 1996-2001', Canadian Journal of Regional Science/Revue Canadienne des sciences régionales, vol. XXXI, no. 1, pp. 117-132.

Mrozik, K, Bossy, M \& Zaręba, K 2012, 'Polityka przestrzenna gmin wiejskich na tle zmian zagospodarowania przestrzennego wynikających z suburbanizacji' ['Spatial policy of rural municipalities based on the changes in spatial development resulting from the suburbanisation'], Rocznik Ochrona Środowiska, vol. 14, pp. 761-771.
Mrozik, K \& Wiśniewska, A 2013, Miejscowe plany zagospodarowania przestrzennego jako instrument zarządzania procesem suburbanizacji na terenach wiejskich na przykładzie obrębu geodezyjnego Skórzewo' ['Local spatial development plans as the managing instrument of the suburbanisation proces in rural areas on the example of geodetic unit Skórzewo'], Rocznik Ochrona Środowiska, vol. 15, pp. 2126-2141.

Nijman, J \& Clery, T 2015, 'Rethinking suburbia: a case study of metropolitan Miami', Environment and Planning, vol. 47, pp. 69-88.

Parysek, J \& Tölle, A (eds.) 2008, Wybrane problemy rozwoju i rewitalizacji miast: aspekty poznawcze i praktyczne' ['Selected problems of a city development and revitalisation: research and practical apsects'], Biuletyn IGSEIGP UAM w Poznaniu, Seria Rozwój regionalny i Polityka Regionalna, vol. 5, Bogucki WN, Poznań, pp. 29-48.

Podawca, K 2015, Dynamika procesów planistycznych w gminach powiatu płockiego w latach 2010-2015' ['The dynamics of planning processes in the municipalities of Płock County'], Notatki Płockie, no 2(255), pp. 24-35.

Podawca, K \& Mrozik, K 2019, 'Dywersyfikacja stopnia realizacji procesów planistyczno-inwestycyjnych w gminach Warszawskiego Obszaru Funkcjonalnego' ['Diversification of planning and investment processes in the municipalities of Warsaw Functional Area'], Scientific Review Engineering and Environmental Sciences, vol. 28(1), pp. 105-117.

Projekt ustawy o ustroju miasta stołecznego Warszawy z dnia 30 stycznia 2017 r. (druk nr 1259) ['Draft of the legal act on the system of The Capital City of Warsaw from 30 January 2017 - draft no. 1259]. Available from:<http://www.sejm.gov. pl>. [26 March 2019].

Roca, J, Burns, MC \& Carreras, JM 2004, 'Monitoring urban sprawl around Barcelona's metropolitan area with the aid of satellite imagery', 20th ISPRS Congress, Istanbul, Turkey, 12-23 July 2004. Available from: <https://pdfs. semanticscholar.org/1a99/4875b350753c4f81d9c33c98180 531af6ce0.pdf>. [26 March 2019].

Sokołowski, D 2015, 'Urbanization of villages on the example of former towns in the Świętokrzyskie Voivodeship', Studia Obszarów Wiejskich, vol. 37, pp. 195-216.

Sołtys, J 2010, 'Struktura miast a zasady rozwoju zrównoważonego - wybrane problemy' [City structure versus the principles of a sustainable development selected problems], Czasopismo Techniczne. Architektura, vol. 14, Wyd. Politechniki Warszawskiej, pp. 13-20.

Sorensen, A 2016, 'Peri-urbanization as the institutionalisation of place. The case study of Japan', Cities, vol. 53, pp. 134-140.

Spórna, T 2018, 'The suburbanisation process in a depopulation context in the Katowice conurbation, Poland', Environmental \& Socio-economics Studies, vol. 6, no. 1, pp. 57-72.

Śleszyński, P 2009, ,O statystycznych ułomnościach pomiaru urbanizacji w Polsce' ['On statistical shortages of the urbanisation measures in Poland'], Geografia w Szkole, vol. 3, pp. 31-34.

Śleszyński, P (ed.) 2012, ,Warszawa i obszar metropolitalny Warszawy a rozwój Mazowsza' ['Warsaw and its metropolitan area versus the development of Masovia'], Seria Trendy Rozwojowe Mazowsza, no. 8, Mazowieckie Biuro Planowania Regionalnego w Warszawie, Warszawa, pp. 1-160.

Tivari, A \& Goel, V 2017, 'Urban sprawl causes, effects and remedies for Indian cities', IOSR Journal of Environmental Science, Toxicology and Food Technology (IOSR-JESTFT) vol. 11, no. 11, pp. 61-67.

United Nations, Department of Economic and Social Affairs, Population Division, 2018, World Urbanization Prospects: 
The 2018 Revision. Available from: <https://www.un.org/ development/desa/publications/2018-revision-of-worldurbanization-prospects.html>. [26 March 2019].

Ustawa o samorządzie gminnym z 8 marca $1990 \mathrm{r}$. [legal act of 8 March 1990 'on municipal government'], Dz. U. z 2018 r. poz. 994, 1000, 1349, 1432, 2500 (plain text)

Wei, Ji, Jia, Ma, Wahab Twibell, R \& Underhill, K 2006, 'Characterizing urban sprawl using multi-stage remote sensing images and landscape metrics', Computers, Environment and Urban Systems, vol. 30, no. 6, pp. 861-879.

Woo, M 2014, 'Urban containment policies and urban growth', International Journal of Urban Sciences, vol. 18, no. 3, pp. 309-326.

Zydroń, A \& Szczepański, P 2012, 'Ocena procesu suburbanizacji na przykładzie wybranych gmin powiatu poznańskiego w latach 2001-2010' ['The assessment of the suburbanisation process on the example of selected municipalities of Poznań County between 2001-2010'], Rocznik Ochrona Środowiska, vol. 14, pp. 998-1008.

Zegar, T. (ed.), 2016, Obszar metropolitalny Warszawy w 2015 r. ['Warsaw Metropolitan Area'], Urząd Statystyczny w Warszawie, Mazowiecki Ośrodek Badań Regionalnych, Warszawa. 